[Supporting Information]

\title{
Thermodynamics and Kinetics of Formation of Orientationally Isomeric [2]Pseudorotaxanes between of $\alpha$-Cyclodextrin and Aliphatic Chain-Linked Aromatic Donor-Viologen Acceptor Compounds
}

\author{
Joon Woo Park, ${ }^{* \dagger}$ Hyun Jung Song, ${ }^{\dagger}$ Yoon Joo Cho,${ }^{\dagger}$ and Kwanghee Koh Park ${ }^{\ddagger}$ \\ ${ }^{\dagger}$ Department of Chemistry, Ewha Womans University, Seoul 120-750, Korea \\ ${ }^{\ddagger}$ Department of Chemistry, Chungnam National University, Daejeon 305-764, Korea \\ E-mail: jwpark@ewha.ac.kr
}

\section{Contents}

\section{Synthetic procedures}

1. Synthetic procedure of 1-(3,5-dimethoxybenzyl)-1'-[10-(naphthalen-1-yloxy)decyl]-4,4'-bipyridinium dichloride $\left(4 \cdot \mathrm{Cl}_{2}: 1 \mathrm{NC}_{10} \mathrm{VDMB}\right)$.

2. Synthetic procedure of 3-carbazol-9-yl-propyl-ammonium chloride (5). 5

2. Synthetic procedure of 1-methyl-1'-(3,5-dimethoxybenzyl)-4,4'-bipyridinium chloride (9). 6

\section{Spectra}

Figure S1. $600 \mathrm{MHz}{ }^{1} \mathrm{H}$ NMR spectrum of $1 \mathrm{NC}_{10} \mathrm{~V}, 2$, in $\mathrm{D}_{2} \mathrm{O}$. $-8$

Figure S2. $600 \mathrm{MHz}{ }^{1} \mathrm{H}$ NMR spectrum of a mixture of $1 \mathrm{NC}_{10} \mathrm{~V}, 2$, and $\alpha-\mathrm{CD}$ in $\mathrm{D}_{2} \mathrm{O}$, taken after 3 days of mixing. $-8$

Figure S3. ${ }^{1} \mathrm{H}-{ }^{1} \mathrm{H}$ COSY spectrum of a mixture of $1 \mathrm{NC}_{10} \mathrm{~V}, \mathbf{2}$, and $\alpha-\mathrm{CD}$ in $\mathrm{D}_{2} \mathrm{O}$. --------9

Figure S4. 2D ROSEY spectrum of a mixture of $1 \mathrm{NC}_{10} \mathrm{~V}, 2$, and $\alpha-\mathrm{CD}$ in $\mathrm{D}_{2} \mathrm{O}$. ---------9 
Figure S5. $600 \mathrm{MHz}{ }^{1} \mathrm{H}$ NMR spectrum of $2 \mathrm{NC}_{10} \mathrm{~V}, \mathbf{3}$, in $\mathrm{D}_{2} \mathrm{O}$.

Figure S6. $600 \mathrm{MHz}{ }^{1} \mathrm{H}$ NMR spectrum of a mixture of $2 \mathrm{NC}_{10} \mathrm{~V}, \mathbf{3}$, and $\alpha-\mathrm{CD}$ in $\mathrm{D}_{2} \mathrm{O}-\mathrm{-}-10$ Figure S7. ${ }^{1} \mathrm{H}-{ }^{1} \mathrm{H}$ COSY spectrum of a mixture of $2 \mathrm{NC}_{10} \mathrm{~V}, \mathbf{3}$, and $\alpha-\mathrm{CD}$ in $\mathrm{D}_{2} \mathrm{O}$. -------11 Figure S8. 2D ROSEY spectrum of a mixture of $2 \mathrm{NC}_{10} \mathrm{~V}, \mathbf{3}$, and $\alpha-\mathrm{CD}$ in $\mathrm{D}_{2} \mathrm{O}$. --------11 Figure S9. $600 \mathrm{MHz}{ }^{1} \mathrm{H} \mathrm{NMR}$ spectrum of $1 \mathrm{NC}_{10} \mathrm{VDMB}, 4$, in $\mathrm{D}_{2} \mathrm{O}$. 12

Figure S10. $600 \mathrm{MHz}{ }^{1} \mathrm{H}$ NMR spectrum of a mixture of $1 \mathrm{NC}_{10} \mathrm{VDMB}, \mathbf{4}$, and $\alpha-\mathrm{CD}$ in $\mathrm{D}_{2} \mathrm{O}$, taken after 45 days of mixing. $-12$

Figure S11. ${ }^{1} \mathrm{H}-{ }^{1} \mathrm{H}$ COSY spectrum of a mixture of $1 \mathrm{NC}_{10} \mathrm{VDMB}, \mathbf{4}$, and $\alpha-\mathrm{CD}$ in $\mathrm{D}_{2} \mathrm{O}$. -13

Figure S12. 2D ROSEY spectrum of a mixture of $1 \mathrm{NC}_{10} \mathrm{VDMB}, \mathbf{4}$, and $\alpha-\mathrm{CD}$ in $\mathrm{D}_{2} \mathrm{O} .-13$

Figure S13. (A) Absorption of spectra of 1-DMB, and its $\mathrm{P}_{\mathrm{I}}$ and $\mathrm{P}_{\mathrm{II}}$ type $\alpha$-CD[2]rotaxane isomers. (B) Fluorescence spectra of $P_{I}$ and $P_{I I}$ type [2]rotaxane isomers of 1 -DMB/a-CD. 1-DMB is analogous to 1 having 3,5-dimethoxybenzyl group instead of methyl group at viologen terminal. $-14$

Table S1. Observed rate constants of threading reactions of $\alpha-C D$ with threads 1-4. --15 


\section{Synthesis of 1-(3,5-dimethoxybenzyl)-1'-[10-(naphthalen-1-yloxy)-decyl]-4,4'-}

bipyridinium dichloride $\left(4 \cdot \mathrm{Cl}_{2}: \mathrm{NC}_{10} \mathrm{VDMB}\right)$.

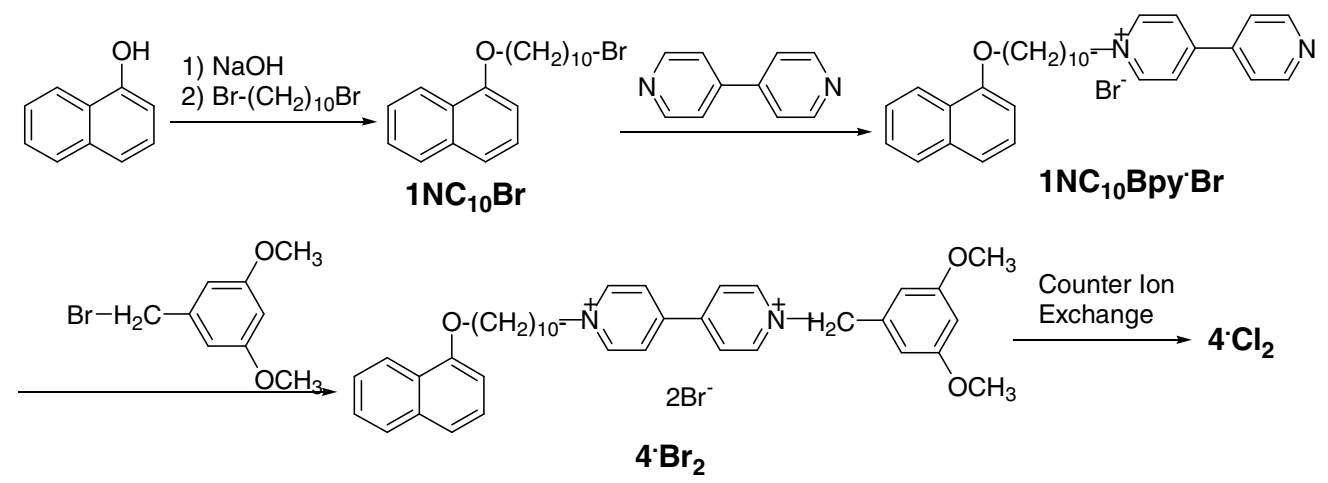

To a solution of 1-naphthol $(2.9 \mathrm{~g}, 20 \mathrm{mmol})$ and $\mathrm{NaOH}(0.80 \mathrm{~g}, 20 \mathrm{mmol})$ in n-propanol (10 mL), 1,10-dibromodecane (12 $\mathrm{g}, 40 \mathrm{mmol})$ was added dropwise and the mixture was stirred for $9 \mathrm{hrs}$ at $50-55^{\circ} \mathrm{C}$. After cooling to room temperature, $n$-hexane (30 mL) was added and the solution was washed with $0.1 \mathrm{M} \mathrm{NaOH}$ (25 mL x 5). After evaporating off n-hexane, silica gel column chromatography of the residue (eluent, n-hexane and then nhexane/ethyl acetate $(10: 1$ by $\mathrm{V} / \mathrm{V})$ afforded $4.0 \mathrm{~g}(55 \%$ yield $)$ of 1-(10bromodecyloxy)naphthalene $\left(1 \mathrm{NC}_{10} \mathrm{Br}\right) .{ }^{1} \mathrm{H} \mathrm{NMR}\left(250 \mathrm{MHz}, \mathrm{CDCl}_{3}, \delta_{\mathrm{TMS}}=0.00 \mathrm{ppm}\right), \delta$ $8.28(\mathrm{~d}, 1 \mathrm{H}), 7.79(\mathrm{~d}, 1 \mathrm{H}), 7.47(\mathrm{~m}, 4 \mathrm{H}), 6.79(\mathrm{~d}, 1 \mathrm{H}), 4.01\left(\mathrm{t}, 2 \mathrm{H},-\mathrm{OC} \underline{H}_{\underline{2}^{-}}\right), 3.18(\mathrm{t}, 2 \mathrm{H},-$ $\left.\mathrm{C}_{2} \mathrm{Br}\right), 1.95\left(\mathrm{~m}, 2 \mathrm{H},-\mathrm{OCH}_{2} \underline{\mathrm{H}}_{2} \underline{2}^{-}\right), 1.84\left(\mathrm{~m}, 2 \mathrm{H},-\underline{\mathrm{H}}_{2} \mathrm{CH}_{2} \mathrm{Br}\right), 1.51\left(\mathrm{~m}, 12 \mathrm{H},-\left(\underline{\mathrm{CH}}_{2}\right)_{6^{-}}\right)$.

A solution of $1 \mathrm{NC}_{10} \mathrm{Br}(0.92 \mathrm{~g}, 2.5 \mathrm{mmol})$ and 4,4-bipyridine $(0.59 \mathrm{~g}, 3.8 \mathrm{mmol})$ in dry acetonitrile $(40 \mathrm{~mL})$ was refluxed for $24 \mathrm{hr}$ under nitrogen atmosphere. After cooling the reaction mixture, precipitates were filtered and then recrystallized from methanol/ethanol mixture (5:1) to give $0.67 \mathrm{~g}$ (51\% yield) of 1-[10-naphthalen-1-yloxy]-decyl]-4,4'bipyridinium bromide $\left(1 \mathrm{NC}_{10} \mathrm{Bpy} \cdot \mathrm{Br}\right) .{ }^{1} \mathrm{H} \mathrm{NMR}\left(250 \mathrm{MHz}, \mathrm{CDCl}_{3}, \delta_{\mathrm{TMS}}=0.00 \mathrm{ppm}\right), \delta$ $9.33(\mathrm{~d}, 2 \mathrm{H}),, 8.89(\mathrm{~d}, 2 \mathrm{H}), 8.26(\mathrm{~d}, 3 \mathrm{H}), 7.85(\mathrm{~m}, 1 \mathrm{H}), 7.63(\mathrm{dd}, 2 \mathrm{H}), 7.45(\mathrm{~m}, 4 \mathrm{H}), 6.82$ 
(d, $1 \mathrm{H}), 4.91$ (t, 2H, - $\underline{\mathrm{H}}_{2}$-bpyr), 4.13 (t, 2H, -OC $\left.\underline{H}_{2^{-}}\right), 3.06$ (m, 2H, $-\underline{C}_{2} \underline{\mathrm{CH}}_{2}$-bpy), 1.96

(m, $\left.2 \mathrm{H},-\mathrm{OCH}_{2} \underline{\mathrm{CH}}_{\underline{2}^{-}}\right), 1.23\left(\mathrm{~m}, 12 \mathrm{H},-\left(\underline{\mathrm{CH}}_{2}\right)_{6^{-}}\right)$.

A DMF $(45 \mathrm{~mL})$ solution of $1 \mathrm{NC}_{10} \mathrm{Bpy} \cdot \mathrm{Br} \quad(0.50 \mathrm{~g}, \quad 0.96 \mathrm{mmol}), \quad 3,5-$ dimethoxybenzylbromide $(0.44 \mathrm{~g}, 1.9 \mathrm{mmol})$, and $\beta$-CD $(3.3 \mathrm{~g}, 2.7 \mathrm{mmol})$ * was stirred for 3 days at room temperature under $\mathrm{N}_{2} .200 \mathrm{~mL}$ of acetone was added to the reaction mixture to obtain $1.3 \mathrm{~g}$ of yellow precipitate. The precipitate was dissolved in water (10 $\mathrm{mL})$ and aqueous hexafluorophosphate solution $(450 \mathrm{mg}$ in $50 \mathrm{~mL}$ ) was added dropwise to the solution to obtain $0.63 \mathrm{~g}$ of hexafluorophosphate salt of $\mathbf{4}$ as precipitate. The precipitate was dissolved in $\mathrm{CH}_{3} \mathrm{CN}(25 \mathrm{~mL})$ and undissolved particulates were removed by filtration. To the filtrate, $630 \mathrm{mg}$ of tetrabutylammonium chloride was added and the solution was hot-bathed for $1 \mathrm{hr}$. After cooling the solution, the precipitate was filtered and recrystallized from $\mathrm{CH}_{3} \mathrm{CN}$ to obtain $0.27 \mathrm{~g}(42 \%)$ of $\mathbf{4} \cdot \mathbf{C l}_{2} \cdot \mathrm{mp} .189{ }^{\circ} \mathrm{C}(\mathrm{dec}) ;{ }^{1} \mathrm{H}$ NMR $\left(600 \mathrm{MHz}, \mathrm{D}_{2} \mathrm{O}, \delta_{\mathrm{HDO}}=4.800 \mathrm{ppm}\right)($ The spectrum is given in Figure $\mathrm{S} 9): \delta 8.98$ $(\mathrm{d}, 2 \mathrm{H}, \mathrm{J}=6.6 \mathrm{~Hz}, \mathrm{H}-2$ '(bpy)), 8.91 (d, 2H, J = 6.6 Hz, H-2 (bpy)), 8.04 (d, 2H, J=6.6 Hz, H-3'(bpy)), 7.96 (d, 2H, J = 6.6 Hz, H-3(bpy)), 7.41 (d, 1H, J = 8.4, H-8 of Nap)), 7.38 (d, $1 \mathrm{H}, \mathrm{J}=8.8 \mathrm{~Hz}, \mathrm{H}-5$ of Nap), 7.30 (t, 1H, J = 7.5 Hz, H-6 of Nap), 7.07 (t, 1H, J = 7.8 Hz, H-7 of Nap), 6.88 (d, 2H, J = 2.4 Hz, H-2 and H-6 of DMB), 6.83-6.77 (m, 2H, H-3 and H-4 of Nap), 6.69 (t, 1H, J = 2.1 Hz, H-4 of DMV), 6.25 (d, 1H, J = 7.2 Hz, H-2 of Nap), $5.73\left(\mathrm{~s}, 2 \mathrm{H},-\underline{\mathrm{CH}} \underline{\mathrm{H}}_{2}\right.$ of DMB), $4.65\left(\mathrm{t}, 2 \mathrm{H}, \mathrm{J}=7.0 \mathrm{~Hz},-\underline{\mathrm{CH}} 2\right.$-bpy). $3.84\left(\mathrm{~s}, 6 \mathrm{H},-\mathrm{O} \underline{\mathrm{CH}}_{3}\right), 3.66$ (t, $\left.2 \mathrm{H}, \mathrm{J}=5.9 \mathrm{~Hz},-\mathrm{OCH}_{2}-\right), 2.02\left(\mathrm{~m}, 2 \mathrm{H},-\underline{\mathrm{CH}_{2}} \mathrm{CH}_{2}-\mathrm{bpy}\right), 1.54\left(\mathrm{~m}, 2 \mathrm{H},-\mathrm{OCH}_{2} \underline{\mathrm{CH}_{2}} 2^{-}\right), 1.2$ $-1.4\left(\mathrm{~m}, 12 \mathrm{H},-\left(\underline{\mathrm{CH}}_{2}\right)_{6^{-}}\right) ; \mathrm{Uv}\left(\mathrm{H}_{2} \mathrm{O}\right): \lambda_{\max } / \mathrm{nm}\left(\log \varepsilon / \mathrm{M}^{-1} \mathrm{~cm}^{-1}\right), 266(4.26)$. Anal. Calcd. for $\mathrm{C}_{39} \mathrm{H}_{46} \mathrm{Cl}_{2} \mathrm{~N}_{2} \mathrm{O}_{3}$ : C, 70.79; H, 7.01; N, 4.23. Found: C, 70.52; H, 6.97; N, 4.21. 
*Addition of $\beta-\mathrm{CD}$ was necessary to promote the reaction presumably by disrupting the intra- and/or intermolecular interaction between naphthoxy and bipyridinium groups.

\section{Synthesis of 3-carbazol-9-yl-propyl-ammonium chloride (5)}

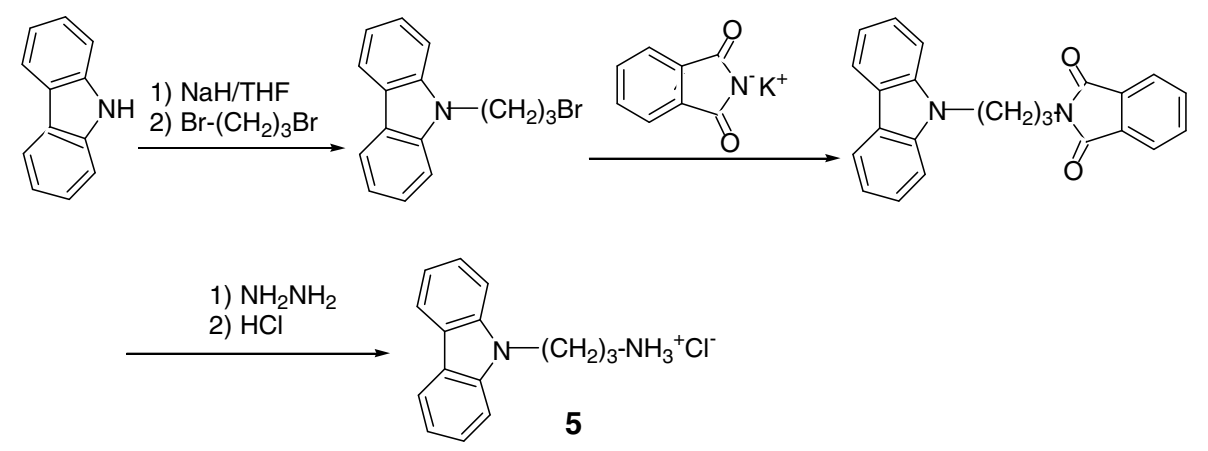

Carbazole (1.6 g, $9.6 \mathrm{mmol})$ was dissolved in dry THF $(40 \mathrm{~mL})$. To the solution, $\mathrm{NaH}(0.46 \mathrm{~g}, 19 \mathrm{mmol})$ was added and the resulting solution was stirred for $2 \mathrm{hr}$ at 40-50 ${ }^{\circ} \mathrm{C}$ under $\mathrm{N}_{2}$ atmosphere. After cooling to rt, 1,3-dibromopropane (3.8 g, $\left.19 \mathrm{mmol}\right)$ was added and stirred under reflux for $3 \mathrm{hr}$. After water $(15 \mathrm{~mL})$ was added to the cooled reaction mixture, the product was extracted with diethyl ether $(20 \mathrm{~mL} \mathrm{x} \mathrm{5).} \mathrm{The} \mathrm{combined}$ ether layer was washed with saturated aqueous $\mathrm{NaCl}$ solution $(100 \mathrm{~mL}$ x 4) and then evaporated to dryness. The crude product was purified by silica-gel column chromatography eluting with n-hexane-benzene $(2: 1, \mathrm{~V} / \mathrm{V})$ mixture to obtain 9-(3bromopropyl)carbazole $(1.1 \mathrm{~g}, 40 \%)$.

9-(3-Bromopropyl)carbazole $(0.84 \mathrm{~g}, 2.9 \mathrm{mmol})$ and potassium phthalimide $(1.1 \mathrm{~g}$, $5.8 \mathrm{mmol}$ ) were dissolved in DMF (20 mL). The resulting solution was stirred for $3 \mathrm{hr}$ at $90{ }^{\circ} \mathrm{C}$. After adding water $(30 \mathrm{~mL})$ to the cooled reaction mixture, the product was extracted with $\mathrm{CH}_{3} \mathrm{Cl}\left(30 \mathrm{~mL}\right.$ x 3). The combined $\mathrm{CH}_{3} \mathrm{Cl}$ layer was washed with aqueous 
1.0 $\mathrm{M} \mathrm{NaOH}$ solution (100 $\mathrm{mL}$ x 3) and evaporated to dryness to obtain $1.8 \mathrm{~g}$ of white solid. The solid was dissolved in $n$-propanol $(20 \mathrm{~mL})$ and hydrazine monohydrate $(1.1 \mathrm{~g}$, $22 \mathrm{mmol}$ ) was added dropwise. After refluxing for $2 \mathrm{hr}$, the solvent was evaporated off and then $1.0 \mathrm{M} \mathrm{HCl}$ was added to adjust $\mathrm{pH}$ to 1.0 . The solution was refluxed for $1.5 \mathrm{hr}$ and $\mathrm{pH}$ was adjusted to 12 with $1.0 \mathrm{M} \mathrm{NaOH}$. The precipitate was extracted with $\mathrm{CH}_{3} \mathrm{Cl}$ (10 $\mathrm{mL} \times 10$ ). The combined $\mathrm{CH}_{3} \mathrm{Cl}$ layer was evaporated, and then white residue was dissolved in anhydrous ethanol. The desired product 5 was recovered as precipitate by the addition of conc. $\mathrm{HCl}$ to the ethanol solution and finally recrystallized from $\mathrm{CH}_{3} \mathrm{CN}$ ethanol (2:1, V/V) mixture. Yield, $0.13 \mathrm{~g}(17 \%) . \quad$ mp. $259{ }^{\circ} \mathrm{C}(\mathrm{dec}) .{ }^{1} \mathrm{H}$ NMR $(250 \mathrm{MHz}$, DMSO- $\left._{6}, \delta_{\mathrm{TMS}}=0.00 \mathrm{ppm}\right): \delta 8.16(\mathrm{~d}, 2 \mathrm{H}, \mathrm{J}=7.7 \mathrm{~Hz}), 7.69(\mathrm{~d}, 2 \mathrm{H}, \mathrm{J}=7.5 \mathrm{~Hz}), 7.50(\mathrm{t}$, $2 \mathrm{H}, \mathrm{J}=7.5 \mathrm{~Hz}), 7.21(\mathrm{t}, 2 \mathrm{H}, \mathrm{J}=7.5 \mathrm{~Hz}), 4.49\left(\mathrm{t}, 2 \mathrm{H}, \mathrm{J}=6.9 \mathrm{~Hz}, \mathrm{Cz}-\underline{\mathrm{CH}} 2^{-}\right), 2.83(\mathrm{t}, 2 \mathrm{H}, \mathrm{J}$ $\left.=7.6 \mathrm{~Hz},-\underline{\mathrm{CH}}_{2} \mathrm{NH}_{3}{ }^{+}\right), 2.04\left(\mathrm{~m}, 2 \mathrm{H}, \mathrm{CH}_{2}-\underline{\mathrm{CH}_{2}}-\mathrm{CH}_{2}\right) . \mathrm{Uv}\left(\mathrm{H}_{2} \mathrm{O}\right): \lambda_{\max } / \mathrm{nm}\left(\log \varepsilon / \mathrm{M}^{-1} \mathrm{~cm}^{-1}\right)$, 234 (4.52), 260(4.21), 291(4.06), 329(3.48), 342(3.50). Anal. Calcd. for $\mathrm{C}_{15} \mathrm{H}_{17} \mathrm{~N}_{2} \mathrm{Cl}: \mathrm{C}$, 69.09; H, 6.57; N, 10.74. Found: C, 69.14; H, 6.69; N, 10.44.

\section{Synthesis of 1-methyl-1'-(3,5-dimethoxybenzyl)-4,4'-bipyridinium chloride (9)}

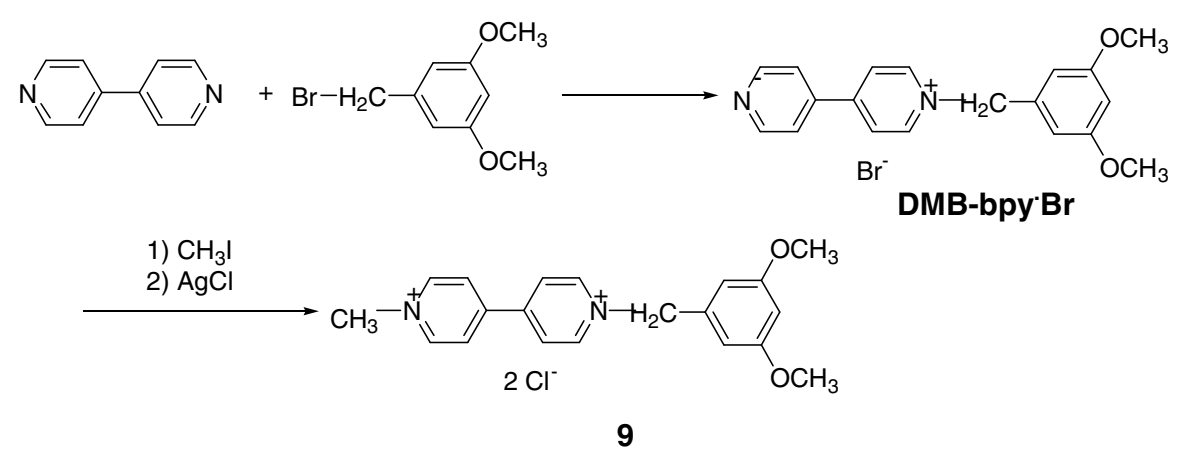

4,4'-Bipyridine (2.7 g, $17 \mathrm{mmol})$ and 3,5-dimethoxybenzyl bromide (2.0 g, $8.7 \mathrm{mmol})$ 
were dissolved in ethanol $(10 \mathrm{~mL})$ and then stirred at $45-50{ }^{\circ} \mathrm{C}$ for $9 \mathrm{hr}$. The precipitate was removed by hot filtration and diethyl ether $(100 \mathrm{~mL})$ was added to cooled filtrate to precipitate the desired product. The precipitate was recrystallized twice from ethanolisopropyl alcohol (1:5 V/V) mixture to obtain DMB-Bpy·Br (2.6 g, $78 \%) .{ }^{1} \mathrm{H}$ NMR (250 $\left.\mathrm{MHz}, \mathrm{D}_{2} \mathrm{O}, \delta_{\mathrm{TMS}}=0.00 \mathrm{ppm}\right): \delta 9.20(\mathrm{~d}, 2 \mathrm{H}), \delta 9.09(\mathrm{~d}, 2 \mathrm{H}), 8.50(\mathrm{t}, 4 \mathrm{H}), 6.78(\mathrm{~s}, 2 \mathrm{H})$, $6.70(\mathrm{~s}, 1 \mathrm{H}), 5.88(\mathrm{~s}, 2 \mathrm{H}), 3.75(\mathrm{~s}, 6 \mathrm{H})$.

To a solution of DMB-Bpy·Br $(2.6 \mathrm{~g}, 6.7 \mathrm{mmol})$ in ethanol $(30 \mathrm{~mL}), \mathrm{CH}_{3} \mathrm{I}(9.5 \mathrm{~g}, 67$ mmol) was added and then was heated at ca $40{ }^{\circ} \mathrm{C}$ for $22 \mathrm{hr}$. The red precipitate was collected by filtration, and washed with hot ethanol twice. The dried precipitate was dissolved in water $(100 \mathrm{~mL})$ and then $\mathrm{AgCl}(4.6 \mathrm{~g}, 32 \mathrm{mmol})$ was added to the aqueous solution. After stirring for $19 \mathrm{~h}$ in dark, the solution was filtered. Evaporation of the filtrate to dryness and then recrystallization of the product from ethanol gave $(2.3 \mathrm{~g}$, $90 \%) . \quad \mathrm{mp}>280{ }^{\circ} \mathrm{C}{ }^{1} \mathrm{H}$ NMR $\left(250 \mathrm{MHz}, \mathrm{D}_{2} \mathrm{O}, \delta_{\mathrm{TMS}}=0.00 \mathrm{ppm}\right): \delta 9.21(\mathrm{~d}, 2 \mathrm{H}, \mathrm{J}=6.8$ Hz, bpy-H), 9.11 (d, 2H, J = 6.6 Hz, bpy-H), 8.59 (t, 4H, J = 7.1 Hz, bpy-H), 6.80 (s, 2H, H-2,6 of benzyl), 6.73 (s, 1H, H-4 of benzyl), 5.91 (s, 2H, $\left.-\mathrm{CH}_{2^{-}}\right), 4.56\left(\mathrm{~s}, 3 \mathrm{H}, \mathrm{N}-\mathrm{CH}_{3}\right)$, $3.80\left(\mathrm{~s}, 6 \mathrm{H},-\mathrm{OCH}_{3}\right) . \mathrm{Uv}\left(\mathrm{H}_{2} \mathrm{O}\right): \lambda_{\max } / \mathrm{nm}\left(\log \varepsilon / \mathrm{M}^{-1} \mathrm{~cm}^{-1}\right), 258$ (4.35). Anal. Calcd. for $\mathrm{C}_{20} \mathrm{H}_{22} \mathrm{Cl}_{2} \mathrm{~N}_{2} \mathrm{O}_{2}$ : C, 61.08; H, 5.64; N, 7.12. Found: C, 60.87; H, 5.75; N, 7.09. 

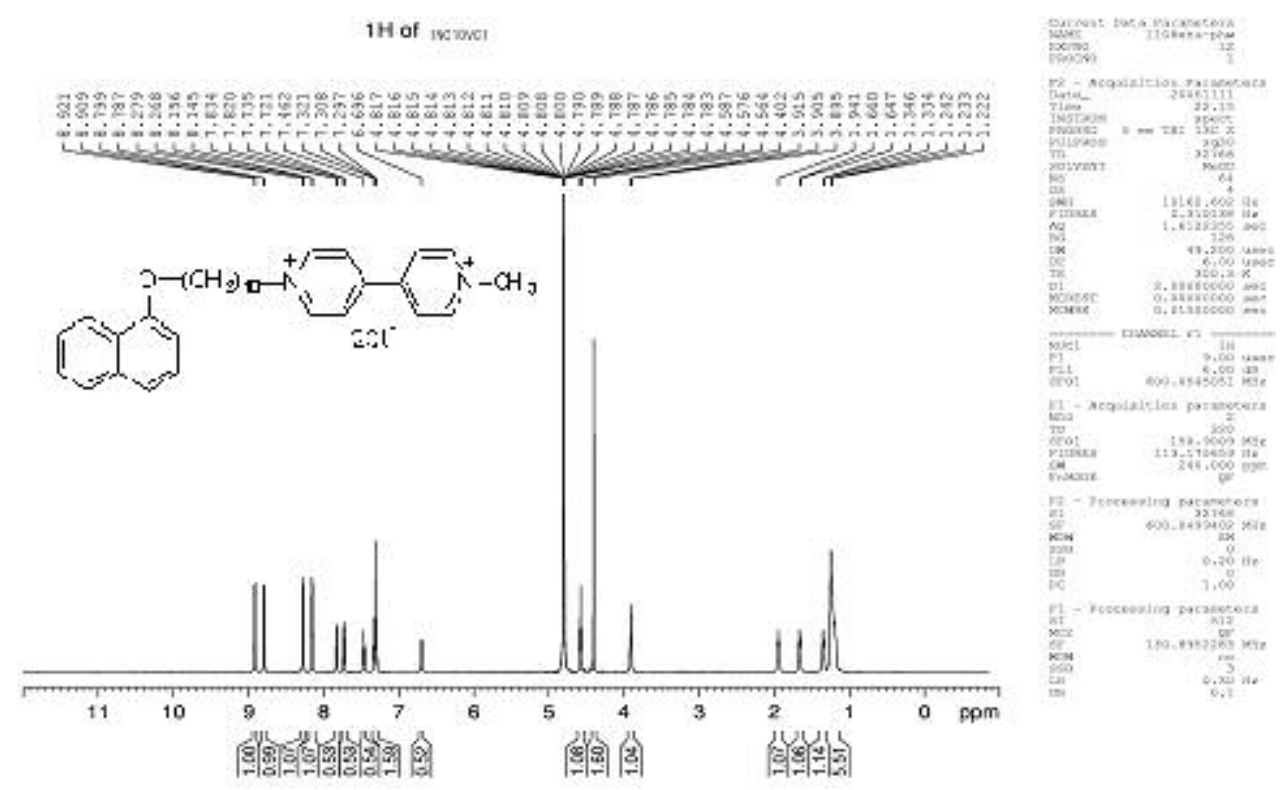

Figure S1. $600 \mathrm{MHz}{ }^{1} \mathrm{H}$ NMR spectrum of $1 \mathrm{NC}_{10} \mathrm{~V}, \mathbf{2}$, in $\mathrm{D}_{2} \mathrm{O}, \delta_{\mathrm{HDO}}=4.800 \mathrm{ppm}$.
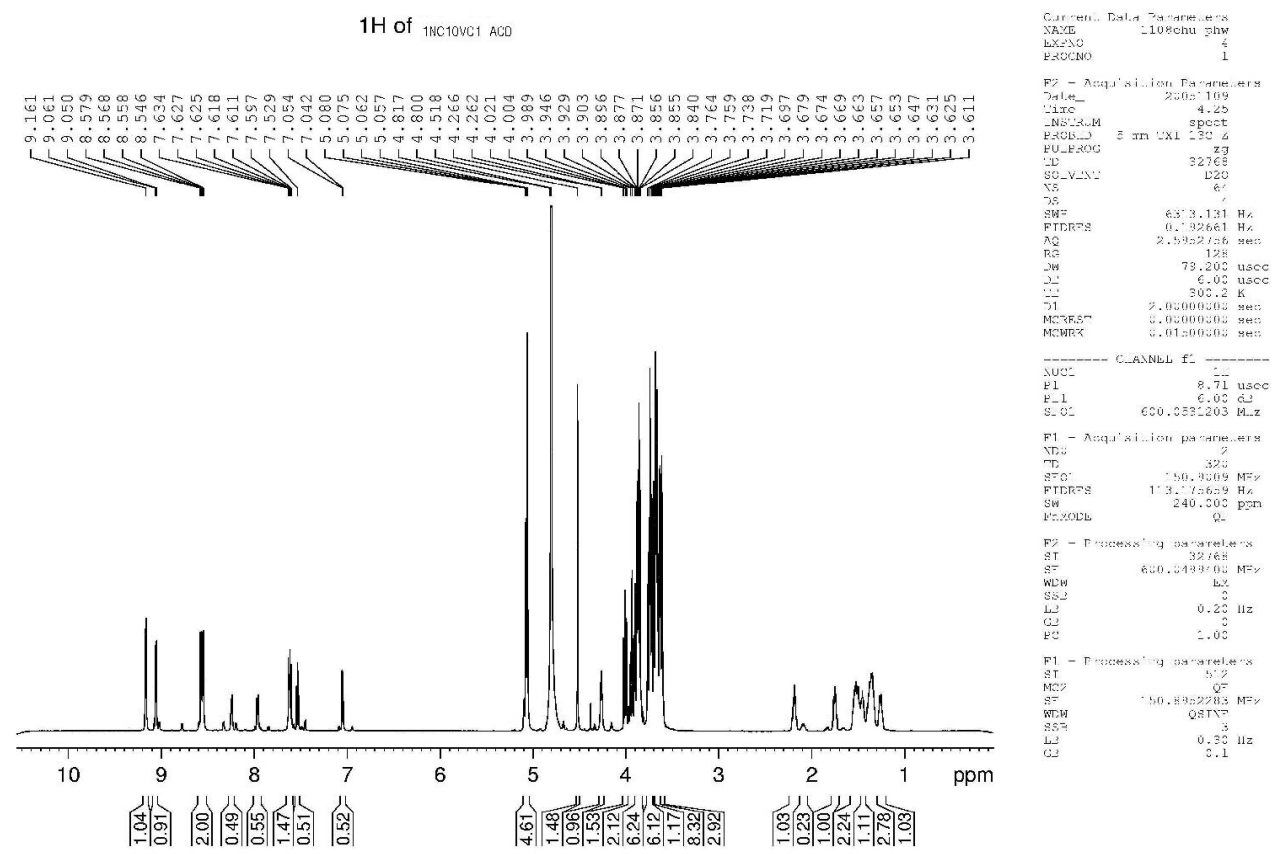

Figure S2. $600 \mathrm{MHz}{ }^{1} \mathrm{H}$ NMR spectrum of a mixture of $1 \mathrm{NC}_{10} \mathrm{~V}, 2$, and $\alpha-\mathrm{CD}$ in $\mathrm{D}_{2} \mathrm{O}$, taken after 3 days of mixing. [2] $=4.9 \mathrm{mM},[\alpha-\mathrm{CD}]=7.1 \mathrm{mM} . \delta_{\mathrm{HDO}}=4.800 \mathrm{ppm}$. 

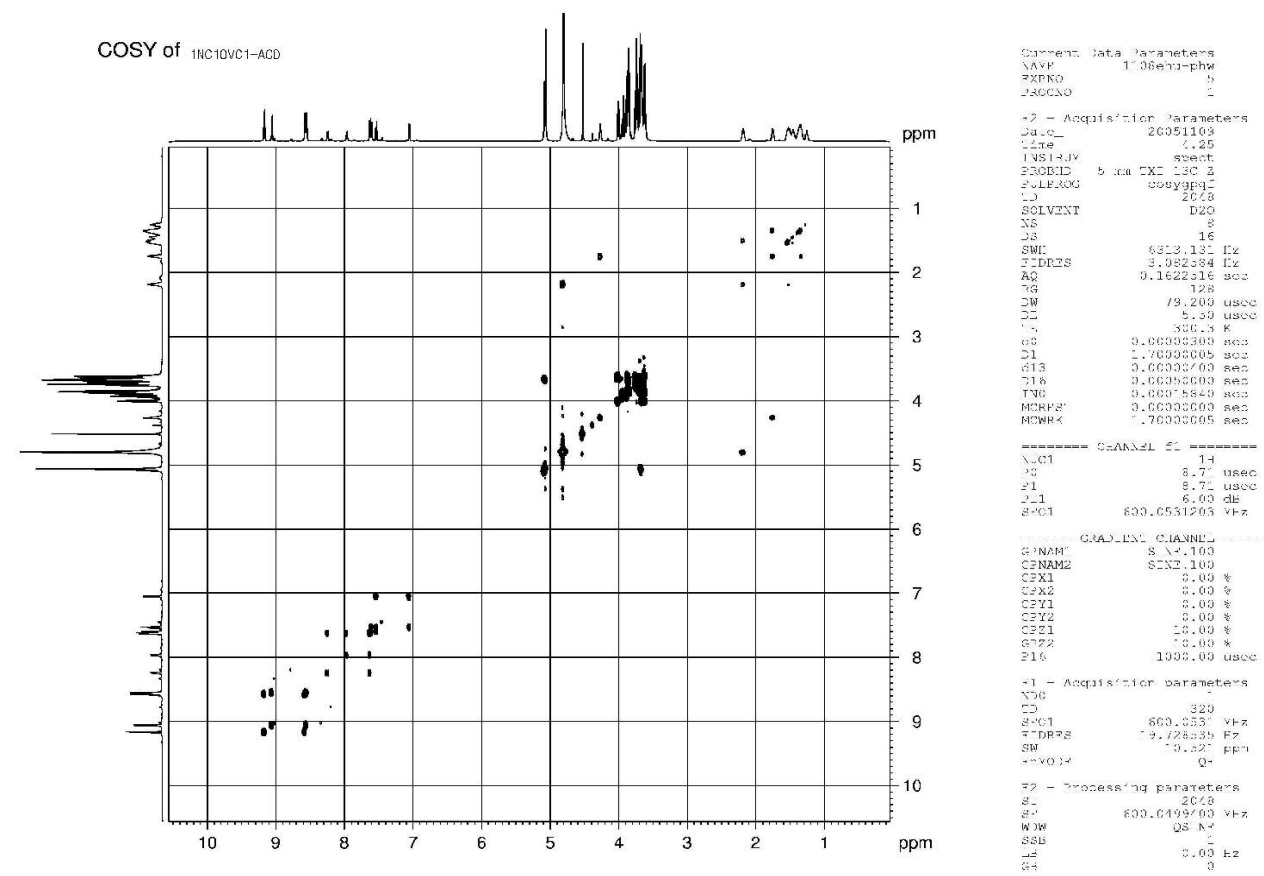

Figure S3. ${ }^{1} \mathrm{H}-{ }^{1} \mathrm{H}$ COSY spectrum of a mixture of $1 \mathrm{NC}_{10} \mathrm{~V}, \mathbf{2}$, and $\alpha-\mathrm{CD}$ in $\mathrm{D}_{2} \mathrm{O}$. Conditions are the same as those in Figure S2.

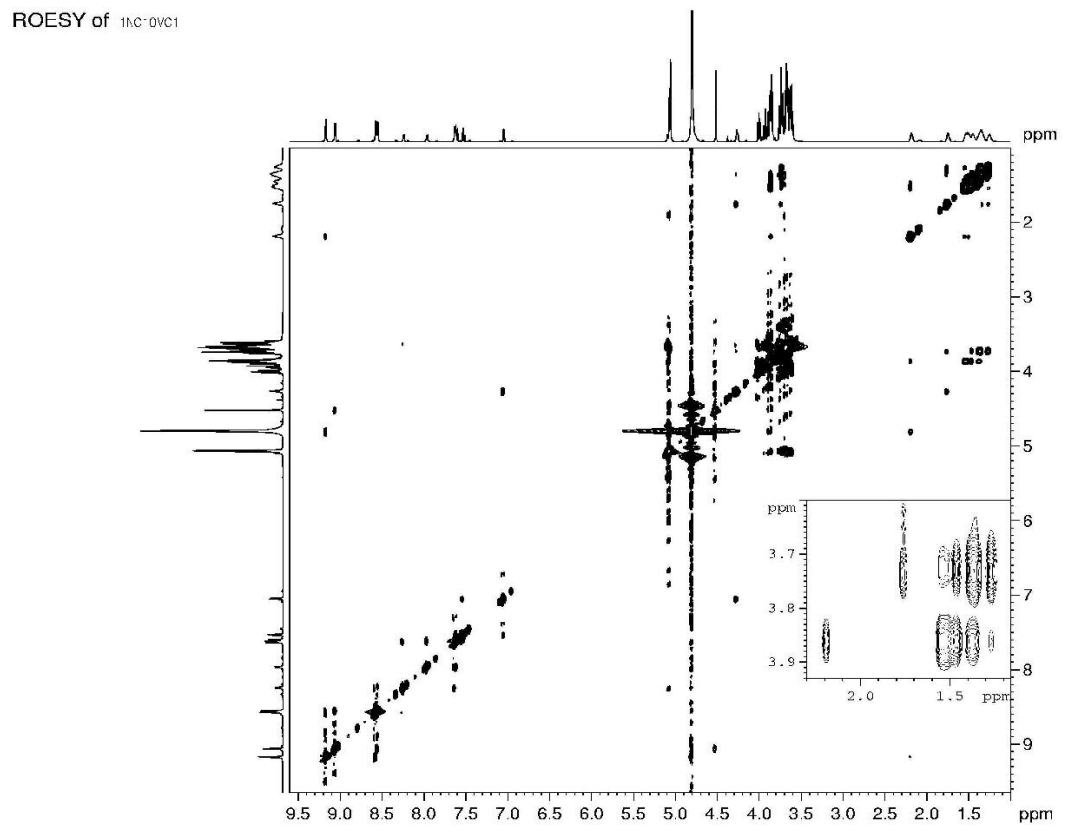

Figure S4. 2D ROSEY spectrum of a mixture of $1 \mathrm{NC}_{10} \mathrm{~V}, 2$, and $\alpha-C D$ in $\mathrm{D}_{2} \mathrm{O}$. Conditions are the same as those in Figure S2. 

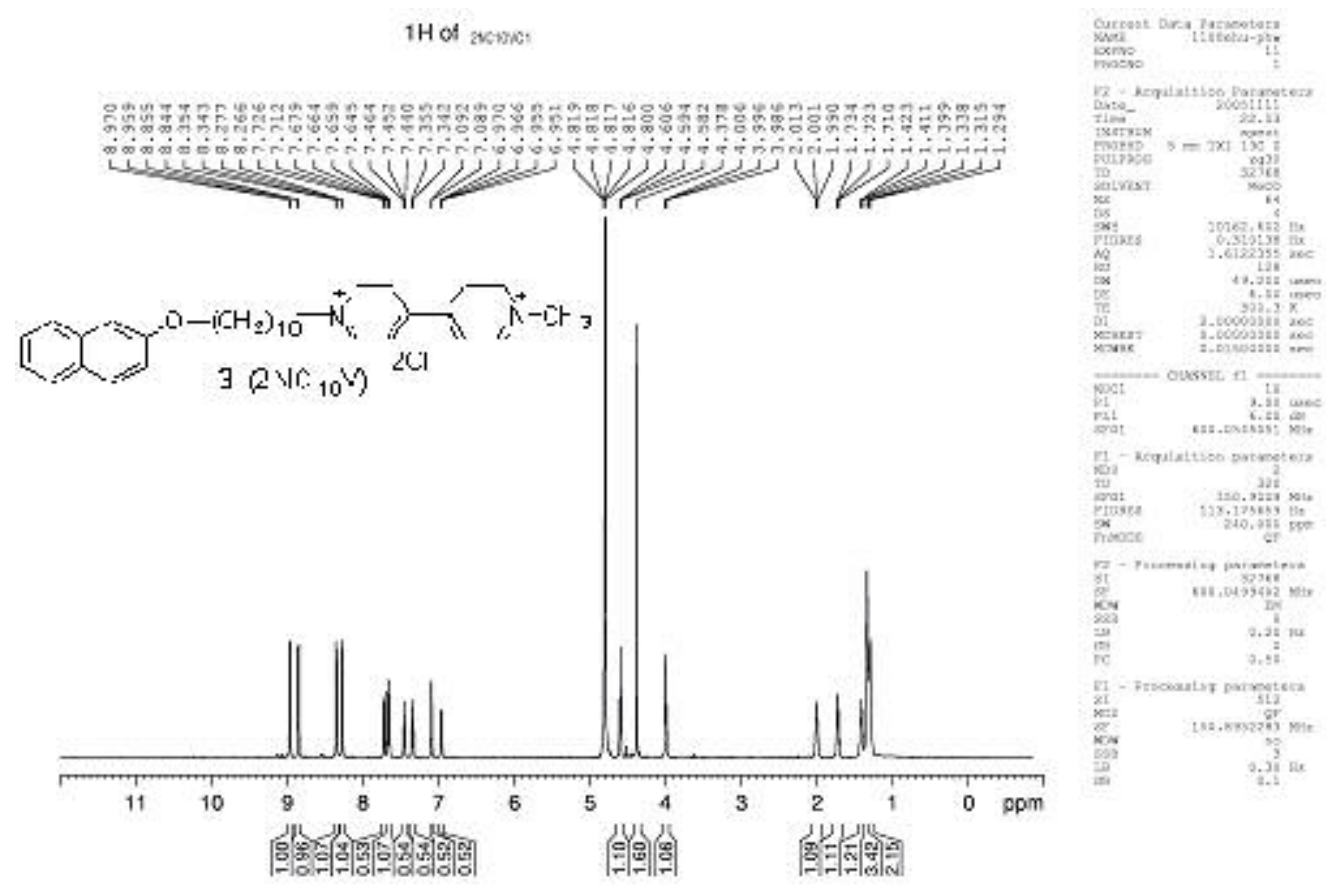

Figure S5. $600 \mathrm{MHz}{ }^{1} \mathrm{H}$ NMR spectrum of $2 \mathrm{NC}_{10} \mathrm{~V}, 3$, in $\mathrm{D}_{2} \mathrm{O}, \delta_{\mathrm{HDO}}=4.800 \mathrm{ppm}$.
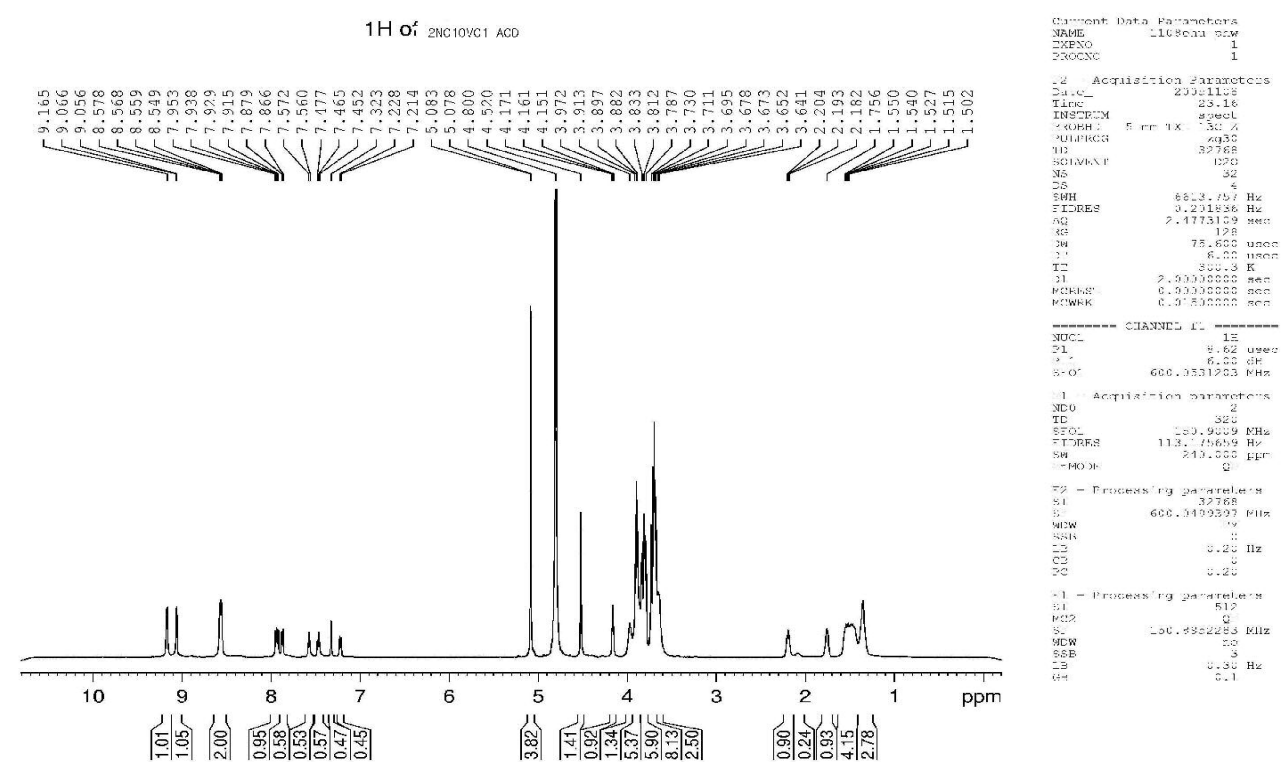

Figure S6. $600 \mathrm{MHz}{ }^{1} \mathrm{H}$ NMR spectrum of a mixture of $2 \mathrm{NC}_{10} \mathrm{~V}, 3$, and $\alpha-\mathrm{CD}$ in $\mathrm{D}_{2} \mathrm{O}$. [3] $=6.0 \mathrm{mM},[\alpha-\mathrm{CD}]=7.7 \mathrm{mM}$. $\delta_{\mathrm{HDO}}=4.800 \mathrm{ppm}$. 

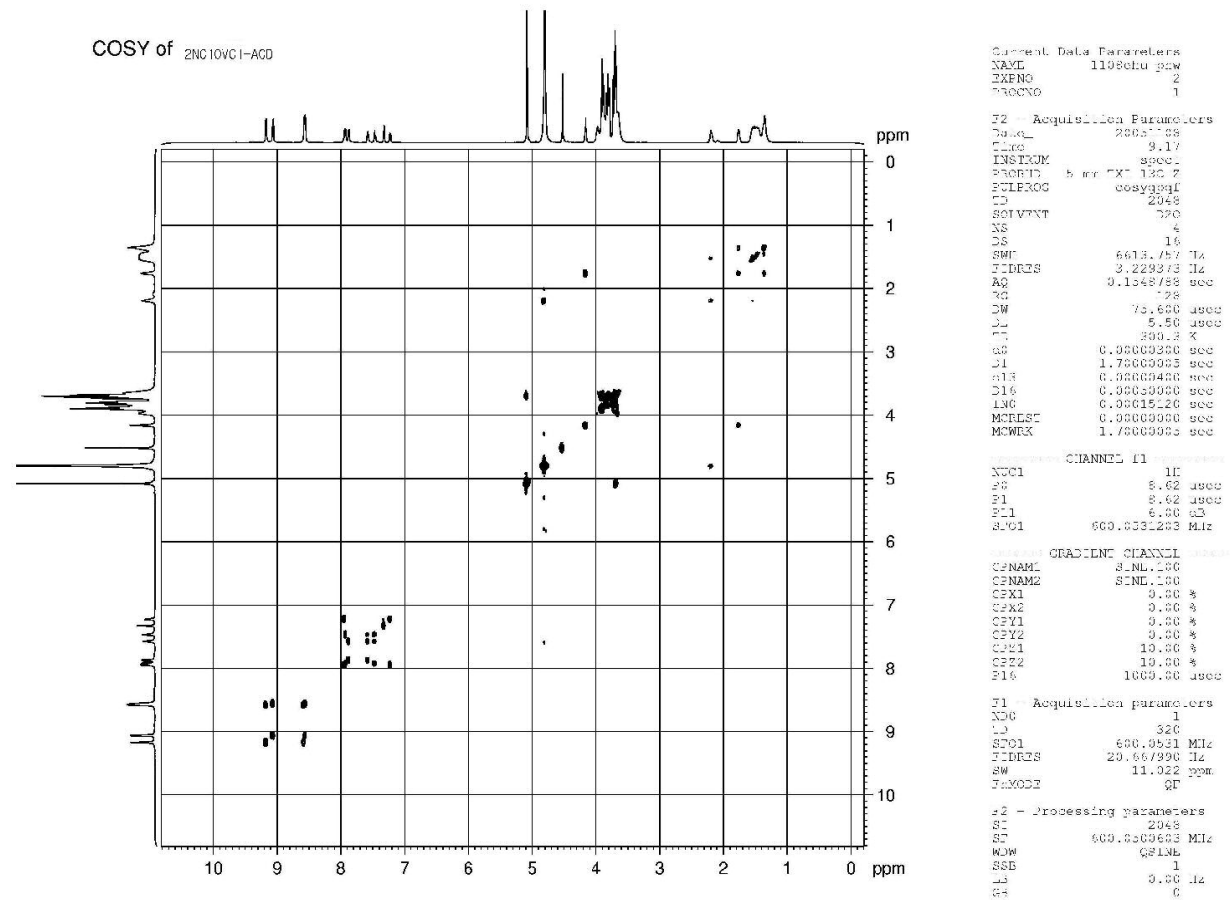

Figure S7. ${ }^{1} \mathrm{H}-{ }^{1} \mathrm{H}$ COSY spectrum of a mixture of $2 \mathrm{NC}_{10} \mathrm{~V}, \mathbf{3}$, and $\alpha-\mathrm{CD}$ in $\mathrm{D}_{2} \mathrm{O}$. Conditions are the same as those in Figure S6.

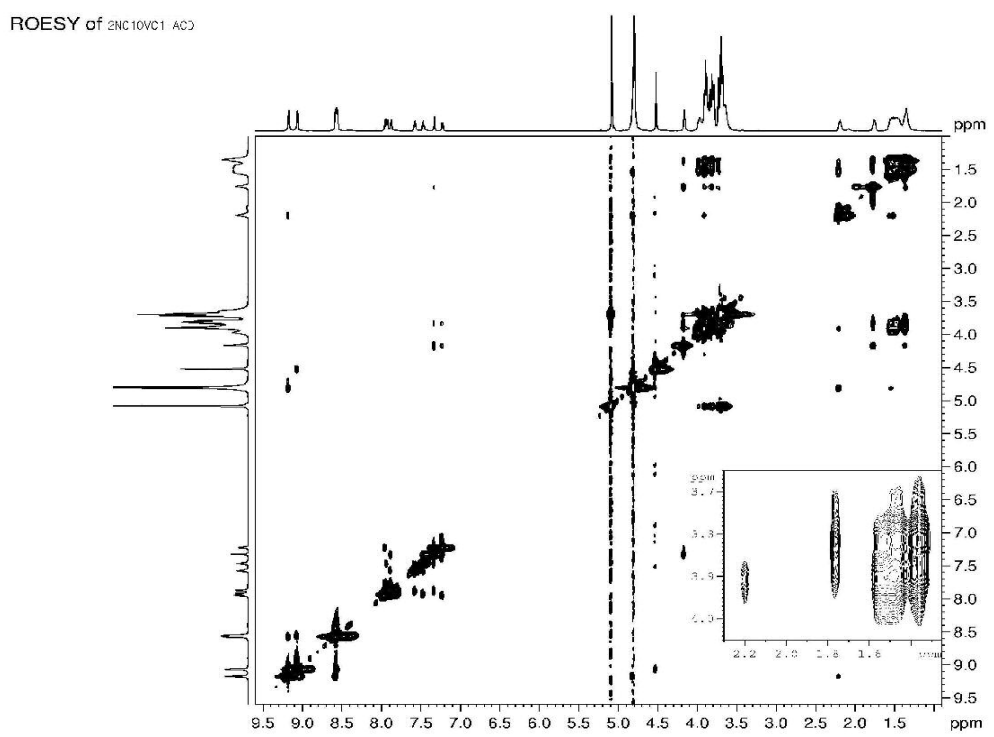

Figure S8. 2D ROSEY spectrum of a mixture of $2 \mathrm{NC}_{10} \mathrm{~V}, \mathbf{3}$, and $\alpha-\mathrm{CD}$ in $\mathrm{D}_{2} \mathrm{O}$. Conditions are the same as those in Figure S6. 

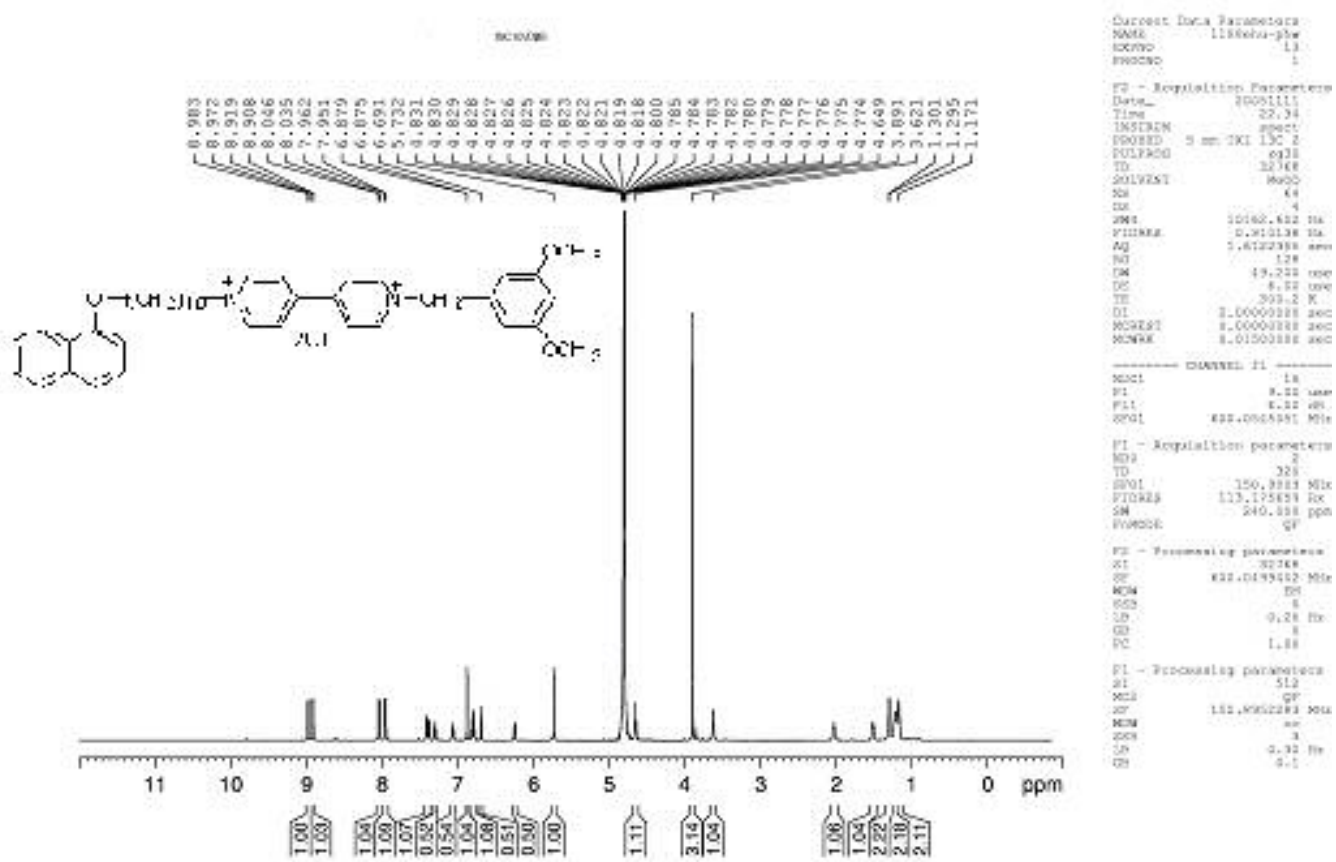

Figure S9. $600 \mathrm{MHz}{ }^{1} \mathrm{H} \mathrm{NMR}$ spectrum of $1 \mathrm{NC}_{10} \mathrm{VDMB}, \mathbf{4}$, in $\mathrm{D}_{2} \mathrm{O}, \delta_{\mathrm{HDO}}=4.800 \mathrm{ppm}$.

$1 \mathrm{H}$ of 1 NC1OYCMB $A \mathrm{CD} \mathrm{H}^{-}$

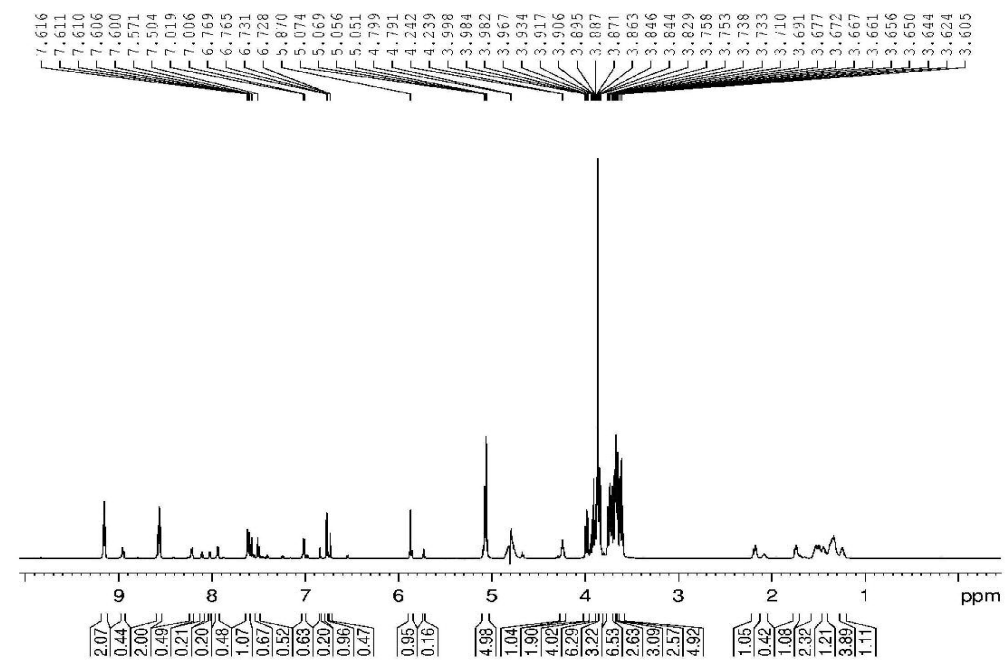

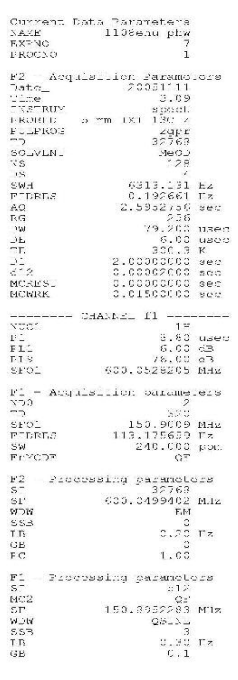

Figure S10. $600 \mathrm{MHz}{ }^{1} \mathrm{H}$ NMR spectrum of a mixture of $1 \mathrm{NC}_{10} \mathrm{VDMB}, 4$, and $\alpha-\mathrm{CD}$ in $\mathrm{D}_{2} \mathrm{O}$, taken after 45 days of mixing. [4] $=5.3 \mathrm{mM},[\alpha-\mathrm{CD}]=7.3 \mathrm{mM} . \delta_{\mathrm{HDO}}=4.800 \mathrm{ppm}$. 


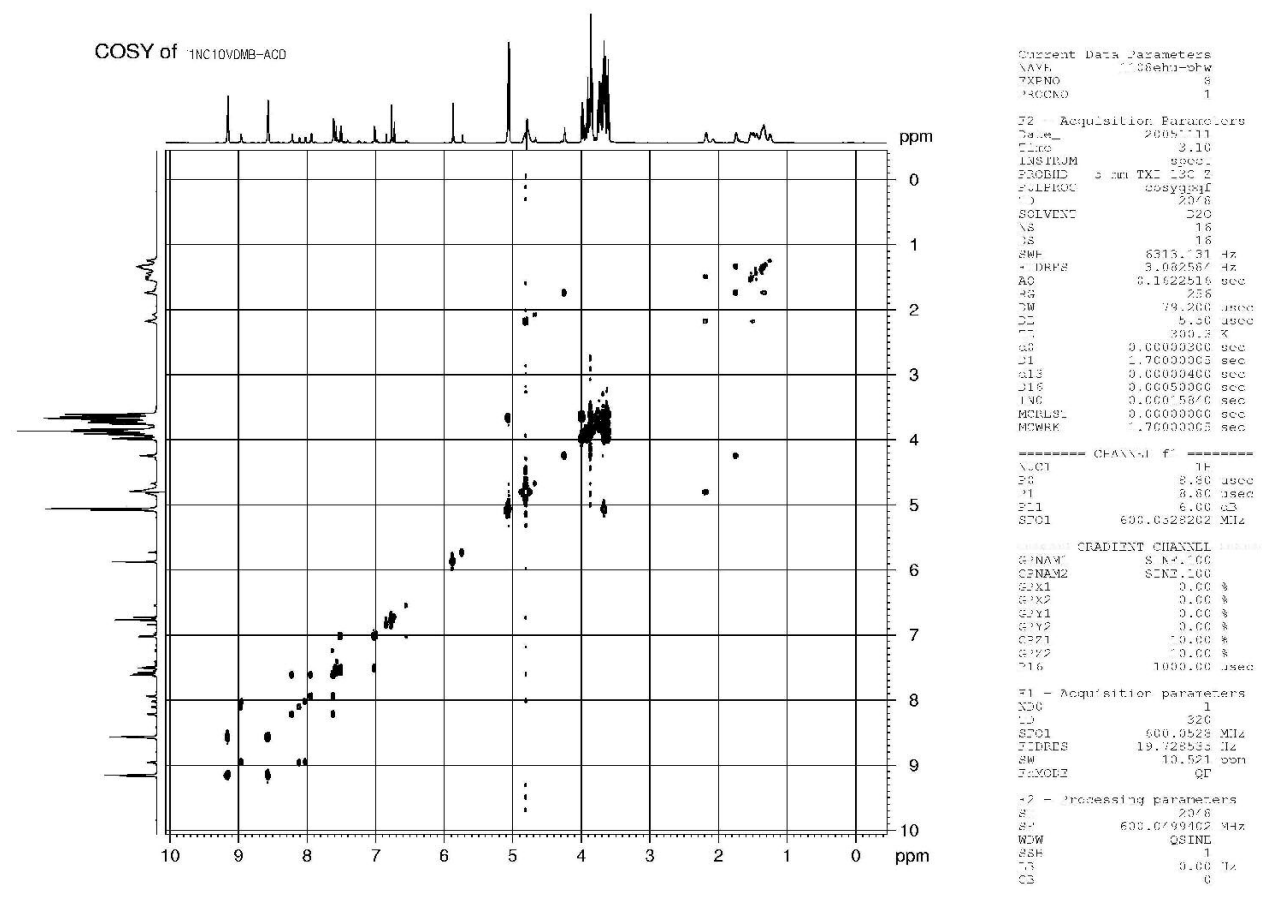

Figure S11. ${ }^{1} \mathrm{H}-{ }^{1} \mathrm{H}$ COSY spectrum of a mixture of $1 \mathrm{NC}_{10} \mathrm{VDMB}, 4$, and $\alpha-\mathrm{CD}$ in $\mathrm{D}_{2} \mathrm{O}$. Conditions are the same as those in Figure S10.

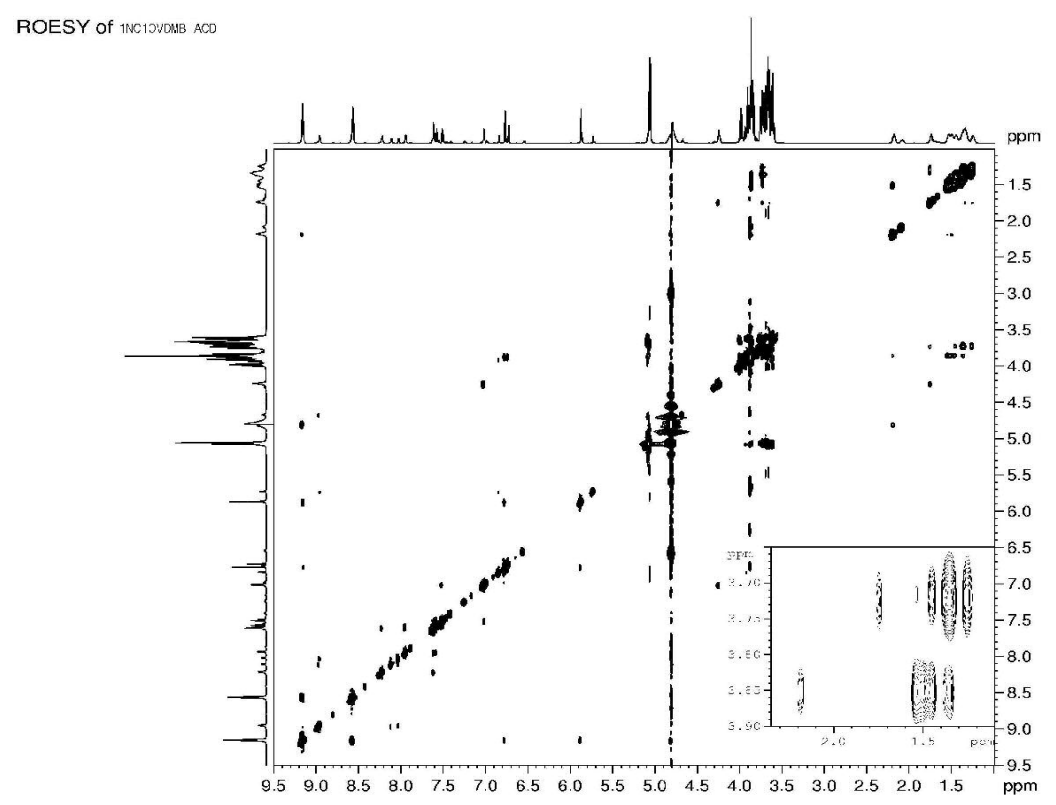

Figure S12. 2D ROSEY spectrum of a mixture of $1 \mathrm{NC}_{10} \mathrm{VDMB}, \mathbf{4}$, and $\alpha-\mathrm{CD}$ in $\mathrm{D}_{2} \mathrm{O}$. Conditions are the same as those in Figure S10. 

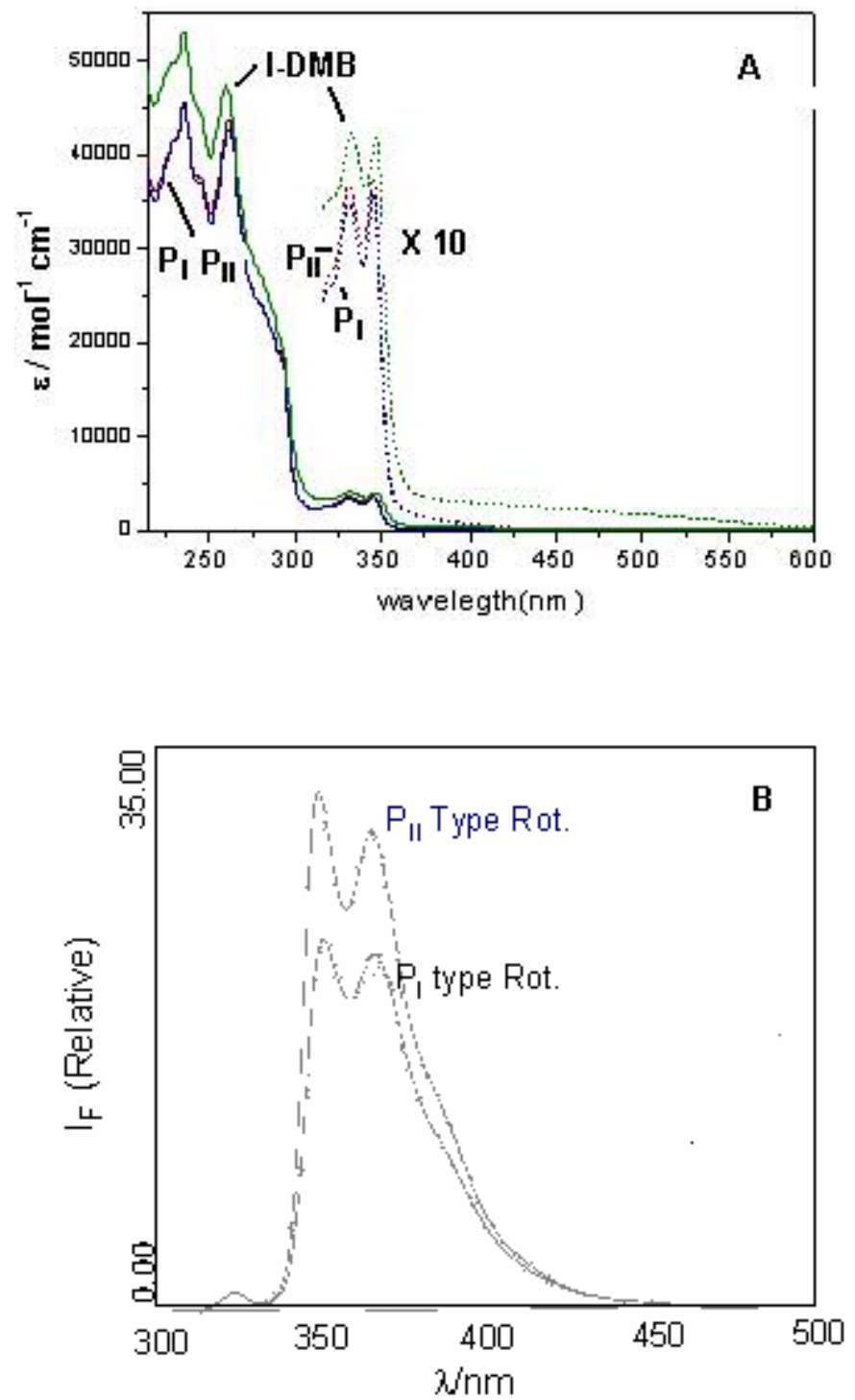

Figure S13. (A) Absorption of spectra of 1-DMB, and its $P_{I}$ and $P_{I I}$ type $\alpha-C D$ [2] rotaxane isomers. The expanded spectra above $320 \mathrm{~nm}$ by 10 times are also shown. (B) Fluorescence spectra of $\mathrm{P}_{\mathrm{I}}$ and $\mathrm{P}_{\mathrm{II}}$ type [2]rotaxane isomers of $1-\mathrm{DMB} / \alpha-\mathrm{CD}(\lambda \mathrm{ex}=$ $328 \mathrm{~nm}$ ). 1-DMB is analogous to 1 having 3,5-dimethoxybenzyl group instead of methyl group at viologen terminal. 
Table S1. The observed pseudo-first order rate constants for the threading reactions of $\alpha$ $\mathrm{CD}$ with $\mathrm{Ar}-\left(\mathrm{CH}_{2}\right)_{10}$-viologen in water at $25.0{ }^{\circ} \mathrm{C}$.

\begin{tabular}{|c|c|c|c|c|c|c|}
\hline thread & & & & & & \\
\hline \multirow{3}{*}{$\mathrm{CzC}_{10} \mathrm{~V}(\mathbf{1})$} & {$[\alpha-\mathrm{CD}] / 10^{-3} \mathrm{M}$} & 0.97 & 1.93 & 2.88 & 3.84 & 4.84 \\
\hline & $k_{1, \mathrm{obs}} / 10^{-3} \mathrm{~s}^{-1}$ & 3.41 & 4.43 & 5.88 & 7.00 & 8.40 \\
\hline & $k_{2, \mathrm{obs}} / 10^{-3} \mathrm{~s}^{-1}$ & 0.42 & 0.49 & 0.57 & 0.74 & 0.63 \\
\hline \multirow{3}{*}{$1 \mathrm{NC}_{10} \mathrm{~V}(\mathbf{2})$} & {$[\alpha-C D] / 10^{-3} \mathrm{M}$} & 0.97 & 1.94 & 2.91 & 3.88 & 4.85 \\
\hline & $k_{1, \mathrm{obs}} / 10^{-3} \mathrm{~s}^{-1}$ & 4.08 & 6.06 & 7.92 & 9.64 & 11.5 \\
\hline & $k_{2, \mathrm{obs}} / 10^{-3} \mathrm{~s}^{-1}$ & 0.71 & 1.00 & 1.11 & 1.35 & 1.25 \\
\hline \multirow[b]{2}{*}{$2 \mathrm{NC}_{10} \mathrm{~V}(\mathbf{3})$} & {$[\alpha-\mathrm{CD}] / 10^{-3} \mathrm{M}$} & 7.99 & 11.7 & 15.9 & 20.2 & \\
\hline & $k_{1, \mathrm{obs}} / \mathrm{s}^{-1}$ & 8.6 & 12.2 & 16.7 & 20.3 & \\
\hline \multirow{2}{*}{$\begin{array}{r}1 \mathrm{NC}_{10} \mathrm{VDMB} \\
\text { (4) }\end{array}$} & {$[\alpha-C D] / 10^{-3} \mathrm{M}$} & 9.7 & 19.4 & 29.3 & 38.1 & \\
\hline & $k_{1, \mathrm{obs}} / 10^{-5} \mathrm{~s}^{-1}$ & 8.1 & 13.0 & 15.6 & 17.9 & \\
\hline
\end{tabular}

$[1]=5 \times 10^{-6} \mathrm{M} ;[2]=[4]=5.0 \times 10^{-5} \mathrm{M} ;[3]=5.7 \times 10^{-4} \mathrm{M}$. 